\title{
Destination Familiarity and Perceived Attractiveness of Four Polish Tourism Cities
}

\author{
Mariusz Szubert, Witold Warcholik and Michał Żemła *D \\ Department of Tourism and Regional Studies, Pedagogical University in Cracow, 30-084 Cracow, Poland; \\ mariusz.szubert@up.krakow.pl (M.S.); witold.warcholik@up.krakow.pl (W.W.) \\ * Correspondence: michal.zemla@up.krakow.pl
}

check for updates

Citation: Szubert, M.; Warcholik, W.; Żemła, M. Destination Familiarity and Perceived Attractiveness of Four Polish Tourism Cities. Sustainability 2022, 14, 128. https://doi.org/ $10.3390 /$ su14010128

Academic Editors: Raquel Camprubí and Ariadna Gassiot-Melian

Received: 1 December 2021

Accepted: 21 December 2021

Published: 23 December 2021

Publisher's Note: MDPI stays neutral with regard to jurisdictional claims in published maps and institutional affiliations.

Copyright: (C) 2021 by the authors. Licensee MDPI, Basel, Switzerland. This article is an open access article distributed under the terms and conditions of the Creative Commons Attribution (CC BY) license (https:// creativecommons.org/licenses/by/ $4.0 /)$.

\begin{abstract}
Destination familiarity has been analyzed for many years as an important factor influencing the perceived attractiveness of a destination and its image. However, previous research has concentrated on this relation considering familiarity with a destination as a whole, while the issue of familiarity with particular elements of a destination has not been explored. The current research aimed to detect if and how familiarity with three selected elements of a destination, namely, tangible tourism attractions, events, and traditional cuisine and dishes, impacts the perceived attractiveness of a city destination. The research was conducted using the following four Polish cities as examples: Gdańsk, Katowice, Łódź, and Wrocław. The research questionnaire was distributed among the citizens of another Polish city-Krakow. Over 200 responses were received. The results show that familiarity with tangible attraction was correlated with high perceived attractiveness of a destination, while the other two factors did not impact the level of perceived attractiveness. The results were achieved on the basis of the indication of several scientific and practical conclusions.
\end{abstract}

Keywords: destination familiarity; destination image; perceived attractiveness; city tourism; tourism attractions

\section{Introduction}

Tourist destinations might be viewed as complex products of the tourism industry, consisting of natural resources, infrastructure, superstructure, services, distinctive local features, and cultural attributes, among others [1,2]. They compete on the free market for tourists visits and expenditures [3]. To be successful in this competition, they have to be able to attract tourists and influence their decision process [4]. As they are usually located far away from tourists' places of living, competition between them is often based not on the actual knowledge about the destinations' offers but, rather, on the images of the destinations. As such, the process of destinations' image formation and its relations with tourists decisionmaking are among the most prominent topics in tourism research [5-9]. Due to a wide body of research, both topics are well recognized, but many details are yet to be discovered.

Tourism attractiveness is a measure of the ability to attract tourists. It can be regarded objectively from the supply side and subjectively from the demand side [10]. The subjective measure of a destination's attractiveness is often labeled as perceived attractiveness. Perceived attractiveness is often considered along with the destination image [11]. Among factors that influence both the destination's perceived attractiveness and the destination's image, familiarity is often pointed out. It is often highlighted that the higher degree of familiarity, the more preferable the image of the destination possessed by particular prospective tourists $[12,13]$. In this context, familiarity might be regarded as comprising both previous experiences with the destination and the level of knowledge on this destination [14]. However, to date, destination familiarity has been regarded as an integrated whole without deeper analysis of how tourists' familiarity (experiences and knowledge) with particular elements of a destination product influence perceived attractiveness. The 
current research explores this relation as an initial study. For this reason, three elements often regarded as important parts of a destination's product were analyzed in the context of their influence on how particular destinations are perceived. These elements are tourism tangible attractions [15-17], cultural events [18-20], and culinary traditions [21-23].

Cities can be regarded as very specific and increasingly important tourist destinations on the contemporary tourism market [24-26]. The fast growing interest of tourists in spending their time in cities brings problems that were not observed in tourist resorts or wildlife destinations $[27,28]$. Often, the problem of overtourism is attributed to cities [29,30]. The tourism product offered in cites is very complex and specific. There are different approaches to defining the notion of the tourism product, including the tourism product of a city; however it is clear that all three elements stated above (tourism-tangible attractions, cultural events, and culinary traditions) may play an important role in the tourism product of a city, and tourists' familiarity with them may influence how they perceive its attractiveness.

The aim of presented research is to analyze if and how familiarity with particular elements of a tourist destination can affect the perceived attractiveness of this destination. As a starting point, three elements of tourist destinations were analyzed: tourist attractions, events, and culinary traditions. The current research used four Polish cities (Katowice, Łódź, Wrocław, and Gdańsk) as example cities. They have different histories and heritages and attract tourists for different reasons. Katowice and Łódź are young post-industrial cities, while Wrocław and Gdańsk are historical cities with rich heritages. To eliminate the impact of differences between perception of inhabitants of places located in different parts of the country, the questionnaire was distributed only among citizens of another polish city-Kraków and its closest environment. The questionnaire was distributed electronically in 2020 .

The paper is organized as follows. It starts with a review of the literature connected with the topic of destination image, destination attractiveness and destination familiarity. Especially, relations between destination familiarity and perceived attractiveness and consumers' market behavior are presented The next part is the justification of the selection of the cities and a short presentation of them. The basis of their tourism attractiveness is underlined, which is necessary for understanding the role of analyzed attractions, events and culinary traditions in the cities. The next parts of the paper contain presentation of the research - the method and the results. Finally, the results achieved are discussed and theoretical and practical implications are stated. The paper fills the gap in the scientific knowledge as it gives the first outline regarding relations between familiarity with particular elements of a destination and its perceived attractiveness in contrast to previous research focused on the familiarity with a destination as a whole.

\section{Perceived Attractiveness and Destination Familiarity}

The ability to attract visitors is an element significantly influencing the competitive, present, and future position of individual destinations. According to the classic definition by $\mathrm{Hu}$ and Ritchie [11], "travel destination attractiveness reflects the feelings, beliefs, and opinions that an individual has about a destination's perceived ability to provide satisfaction in relation to his or her special vacation needs". Another definition suggests that tourist attractiveness is the presence of a certain characteristic, attracting tourists to certain areas due to the natural landscape, climate, historical monuments, and various interesting tourist facilities [31]. In summary, the more attractive a destination is perceived by tourists, the more likely it will be selected as a tourist destination [32].

Whether a given site or town is attractive to tourists is determined, on the one hand, by objective factors, such as the presence of natural and anthropogenic values or the relevant elements of tourist and para-tourism infrastructure and, on the other hand, by subjective perception of all these factors by tourists, investors, and residents [33,34]. Similarly, the assessment of tourist attractiveness can be made using objective methods, focused on the analysis of the supply side (e.g., valuation or taxonomy) [35], or subjective methods, based on the analysis of demand with the use of visitor surveys [11]. Formica and Uysal [10] 
indicate the need to use both of these approaches jointly. The same authors also point to the interest of representatives of various sciences in the issue of tourist attractiveness as the basic reason for the existence of two different approaches. The supply approach is typical for spatial planners and geographers, while the demand approach is more often used in the work of researchers in the fields of management, marketing, and market psychology [10]. Following that concept, Kowalczyk [31] indicates three meanings of tourist attractiveness: attractiveness determined by various types of classifications, categorizations, etc. (ideographic attractiveness); attractiveness resulting from the adoption of a specific evaluation technique; and attractiveness resulting from subjective perception.

Tourism attractiveness regarded according to the objective, supply approach is a complex concept and should be considered comprehensively [36]. This ability is enhanced by destination attributes, which can be classified in a variety of ways $[36,37]$. It is determined by tourist attractions, transport accessibility, and the supply of services related to the development of the visited areas. Therefore, it is a concept that integrates the elements that constitute the basis for the development of tourism, that is, tourist attractions with the conditions necessary to satisfy the needs of this movement in the form of an appropriately educated tourist infrastructure [38]. According to this approach, it is necessary to identify the attributes that prompt tourists to choose one destination over another [36]. Tourist attractiveness can be defined as the degree of saturation of the separated spatial systems with factors grouped into four systems of characterizing variables [33]:

- The multiplicity and quality of natural values, which are the primary forces that determine the emergence and development of tourism in a given area;

- $\quad$ The degree of tourism development;

- The transport accessibility of the region and providing tourists with adequate mobility in the region;

- $\quad$ The level of pollution of the natural environment.

The methods of assessing tourist attractiveness, focused on the analysis of the potential of the tourist destination, allow one to analyze objectified quantitative data, which is their significant advantage, but this is also a limitation, because it is difficult to take into account the non-measurable qualitative elements related to the tourist attractiveness of a given area [10]. Thus, these methods make it possible to objectively compare even a larger number of tourist destination areas; however, they measure not so much the real power of attracting tourists but, rather, the potential of individual destinations to generate this force [39]. According to Formica and Uysal [10], it is characteristic mainly of research of a geographic and planning nature. Studies have been carried out to determine the attractiveness of a tourist destination on the basis of attribute analysis of a destination by Ritchie and Zins [40], Gearing et al. [41], Tang and Rochananond [42], and other scientists.

The subjective assessment of tourist attractiveness is often related to the concept of the destination image [43,44], and uses methods developed for the needs of multidimensional analysis of this image $[6,8,12,32,45]$. Researchers often use the concept of the destination's perceived tourist attractiveness [43,46-48]. The survey method has advantages and disadvantages that are opposite to those of the inventory methods. This method measures the real power of attracting tourists, but it is based on the subjective opinions of the respondents, which may be subject to strong fluctuations in time as a result of their (respondents) subsequent experiences and messages (also marketing messages) received from their environment. This method is also more often used to assess the tourist attractiveness of a single area than for comparisons, although such application is not impossible [39].

The destination image has been defined as an impression that a person holds about a state in which they do not reside [49]; as the sum of the beliefs, ideas, and impressions that a person has of a destination [5]; or as the mental construct developed by a potential tourist on the basis of a few selected impressions among the total impressions [50]. Gallarza et al. [51] have proposed a conceptual model of the destination image featuring its complex, multiple, relativistic, and dynamic nature. Recent studies have simultaneously made use of both a multi-attribute approach as well as holistic impressions of the tourist site to determine its 
image or attractiveness [12,52,53]. The main weakness of the multi-attribute approach is that the attribute lists of the destination may be incomplete. Moreover, the sum or average of attribute scores is never an appropriate assessment of the overall attractiveness of the destination. Echtner and Ritchie [6], therefore, mention that complete operationalization of the destination image or attractiveness involves measuring both attributes and holistic impressions of the place [2].

Beginning with Echtner and Ritchie [6], destination image studies have further defined the destination image as a bidimensional construct, comprised of a cognitive (perceptual) domain and an affective (evaluative) domain. The cognitive domain focuses on an individual's knowledge and beliefs about a destination's functional attributes $[32,54]$. The affective domain focuses on an individual's feelings toward the destination and the experiences provided there $[53,55,56]$.

Numerous studies show significant differentiation of the possessed image between people who have previously visited a given destination and those who have not yet had direct contact with this place $[57,58]$. Most of them show a positive relationship between the act of visiting a destination earlier and the intention to visit again $[57,59,60]$, a positive attitude and activities undertaken at the destination [61], or a more positive image [62]. An obvious observation is also the fact that earlier visits to a destination make its image more realistic [8]. A simple statement about the influence of previous experiences of a tourist on their destination image requires significant details in terms of what may be considered as previous experience, what its "intensity" was, and it depends on the scale of impact of this experience on the image. First, the concept of familiarity used in some works analyzing image formation does not always have to be equated to previous visits, such as in the study conducted by Baloglu and McCleary [12]. A certain degree of knowledge and, therefore, more real knowledge, can also be acquired by a person by realizing their particular interest in a specific place expressed through the study of the literature, or by contacts and conversations with people who have previously visited the place. Additionally, information acquired from different sources influences the knowledge a tourist possesses about a particular place. Moreover, also in the case of people who have personally visited a given destination, the scale of the impact of this experience will depend on the number of these visits, their frequency, the nature of the visit and activities carried out during the visit, the length or the time that has elapsed since the last visit, and other factors. Considering the above, it is not surprising that there is a lack of agreement as to the scale and the detailed way in which previous experiences affect the image, which can be observed in the results of empirical research on this phenomenon.

Destination familiarity is often split into several dimensions, including self-rated familiarity, informational familiarity, and experiential familiarity $[11,13,63,64]$. Self-rated familiarity is a tourist's overall level of familiarity with a destination [64], while informational familiarity reflects the amount of destination-related information to which individuals are exposed via various sources [63], and, finally, experiential familiarity refers to one's previous experiences when visiting a destination $[13,63]$.

Destination familiarity is one of the most commonly investigated antecedents of consumer behavior in tourism, such as information search behavior [14], visit intention [65-67] and decision-making processes [68]. In other research [69] the moderating role of destination familiarity between the destination image and its components and intention to visit was investigated. Additionally, the contemporary literature proves that the level of familiarity can have an important, direct impact on information search behavior, and it might be a significant determinant of which external information source is likely to be used [14]. When tourists choose to visit destinations, subjective knowledge of a destination can supplement external information sources in decision making. Lee et al. [70] posited that tourists often accumulate destination-specific knowledge as familiarity increases. Greater knowledge can provide a sense of comfort and confidence in a destination choice [71].

While the relationship between familiarity of a destination perceived as a whole and the destination image has clearly been detected, the question about how knowledge and 
experiences with particular elements of the destination are linked with the image remains without a precise answer. It is clear that both previous experiences with a destinations and information clues regarding the destination never concern all elements of this destination. In this context, the scientific understanding of the impact of particular elements and their familiarity on perceived attractiveness of the destination is crucial. Among rare examples of works deliberating the relationships between individual elements of a destination and the perception of this destination, the paper produced by Kessign et al. [72] can be highlighted. The cited authors turned our attention to the importance of attractions located in a destination in the stated context, but the subject of the research was the residents' familiarity with attractions and how it influences the overall destination image. However, it is logical that tourism attractions might be among the most significant elements of a destination that influence its image. As such, tourist attractions and, more precisely, tangible attractions, were selected for the current research as a potential factor via which familiarity may influence the perceived attractiveness of a destination.

Hypothesis 1 (H1). Familiarity with tangible tourist attractions of a destination is correlated with a more preferable perception of the attractiveness of the destination.

For comparison, a further two elements of a destination were selected, namely, events (mainly cultural, sporting, and business events) and culinary traditions and local foods. To date, these elements have not yet been considered in the context of their familiarity in tourism. Among rare exceptions of works analyzing familiarity with some elements of culinary traditions, papers by Ha and Jang [73] and Horng et al. [66] can be pointed out. However there is a different perspective taken in those papers. They analyze familiarity with a destination as a whole but the destination image is detected among participants of culinary tourism. Finally, it can be rather surprising that the topic of events was not researched so for in the context of destination familiarity. Severt and Hahm [74] in their study measured the perceived destination image, familiarity, and future intentions to visit Alabama among those who had visited and those who had not visited this state and compared current findings to a 2014 study to determine if there was any change over time that might have been caused by a political event-a special election for the United States Senate in 2017.

Hypothesis 2 (H2). Familiarity with events of a destination is correlated with a more preferable perception of the attractiveness of the destination.

Hypothesis 3 (H3). Familiarity with culinary traditions and local food of a destination is correlated with a more preferable perception of the attractiveness of the destination.

\section{Selection of the Cities}

To achieve the goal of the current study, the method of diagnostic survey was chosen, and the survey questionnaire research technique was used. The questionnaire, developed by the authors of the article, contained six closed questions. The subjects covered the first associations and suggested terms that describe four Polish cities: Katowice, Wrocław, Łódź, and Gdańsk (Figure 1); respondents' experiences with these spaces; and the assessment of their tourist attractiveness. 


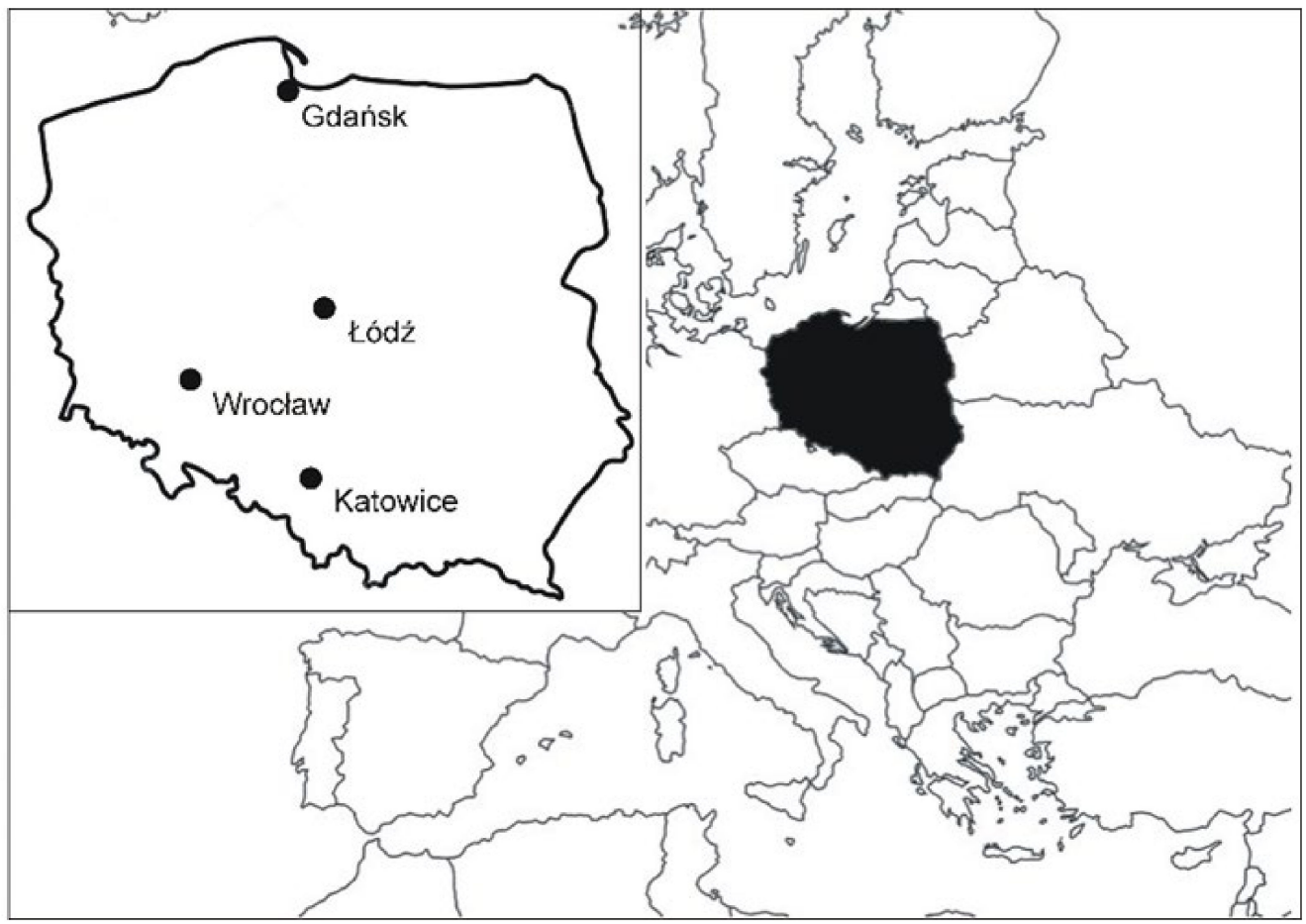

Figure 1. Locations of the cities studied.

Presented research uses four Polish cities (Katowice, Łódź, Wrocław, Gdańsk) as an example. They have different histories and heritage and attract tourists with different offers. In this work the selection of cities and the range of questions regarding tourist attractions referred to the concept of cultural heritage tourism, the idea of cultural heritage and its interpretation. Gdańsk and Wrocław are tourist centers with a very well-developed tourist function based on several hundred years of cultural heritage. They are contrasted with Łódź and Katowice, which are not perceived as tourist cities. They arose in the nineteenth century in connection with the development of industry. The industrial function in these cities developed dynamically until the end of the 1980s. The changes occurred along with the socio-economic changes related to the collapse of the communist system. After 25 years, the economic importance of industry decreased in favor of services, including tourism, in both of these cities. Tourism space was created in post-industrial areas and facilities. Below, there is a short presentation of particular cities intended to help to understand the local context of the cities and underline some of the elements (attractions, events and culinary traditions) to be researched.

The advantage of Gdańsk is its coastal location (on the Gdansk Bay). It is the largest tourist center on the Polish coast and the largest city in the so-called Tricity (Gdańsk, Sopot, Gdynia). Cultural tourism is concentrated in the historic parts of the city: Main Town, Old Town and Oliwa. On the Bay of Gdańsk there are bathing and summer resorts-former fishing villages. Gdańsk's cultural heritage reflects the city's complex history and port function. The President's List of Historic Monuments includes the Main Town, the Old Town, the Gdańsk Shipyard, Westerplatte, the Wisłoujście Fortress and the post-Cistercian and cathedral complex in Oliwa. Cultural heritage tourism is concentrated along the Royal Route (Main Town, Długi Targ Street and Długa Street). The most valuable historical objects are concentrated there-symbols of Gdańsk, Rathaus, Artushof, Neptune fountain, gates, houses and palaces. Nearby, there is the monumental Gothic St. Mary's Church, the former port crane and the city gate-Crane. The heritage related to the outbreak of World War II is represented by: Westerplatte, the Polish Post Office and the Museum of the Second World War. The phenomenon of Gdańsk consists in the harmony of Gothic architecture and Dutch mannerism combined with the atmosphere of the former Hanseatic city and the multiculturalism of the port city. Gdańsk is a destination for sightseeing tourism and a city 
visited during summer holidays by the sea-also in the neighboring tourist centers-Sopot and Gdynia, as well as in more distant resorts.

Wrocław is the capital of Lower Silesia-a historical land in south-west Poland. Symbols related to the history of the city can be found on the islands of Ostrów Tumski and Ostrów Piaskowy. Both of these islands, together with the complexes of monuments, are Monuments of History. Cultural heritage tourism is concentrated on the two mentioned islands and in the historic center (the square and its surroundings, including the university). Tourists are also attracted by the Centennial Hall (site on the UNESCO World Heritage List), the botanical garden and the zoo. The uniqueness of Wrocław is the interpenetration of the past and the present in the cultural landscape of the historical districts of this city. Cultural heritage tourism is based on the symbols of the city's history, including on sacred monuments-monumental Gothic structures or temples enchanting with the splendor of the Baroque. The cultural heritage also includes such tourist attractions as: Grunwaldzki Bridge, Aula Leopoldina (Museum of the University of Wrocław) and the National Museum "Panorama Racławicka" in Wrocław. In this heritage, we find the intermingling of Polish, Czech and German cultures, which is a record of the complex history of the city and Lower Silesia. Cultural tourism is also developing thanks to numerous cultural events. In 2016, Wrocław was the European Capital of Culture.

For several centuries, Katowice was a village which, along with the development of railways and industry, turned into a city in the second half of the 19th century (1865). Within Katowice there are former mining settlements around hard coal mines or steel mills, which are now districts of this city. One of them is Murcki, where the oldest hard coal mine in Upper Silesia (1769) is located. Over the next centuries, Katowice grew into the largest city of the Upper Silesian conurbation and an industrial center, mainly of hard coal mining and metallurgy. Currently, this industrial activity has been severely limited and the former post-industrial areas are being revitalized. Post-industrial heritage has become one of the important factors in the development of cultural tourism in Katowice. The Silesian Industrial Monuments Route passes through the city, with the former mining estates Giszowiec and Nikoszowiec (Monument of History) and the Porcelain Factory "Bogucice". The Silesia City Center has been established in the former post-mining area. A successful example of revitalization is the Katowice Culture Zone built on the site of the former Katowice hard coal mine. It houses the Silesian Museum, the International Congress Center and the Polish National Radio Symphony Orchestra. The "Spodek" Sports and Entertainment Hall is located in the vicinity. The revitalized area of the former mine is now a space for cultural tourism, and mainly consists of cultural heritage, museums, congresses, business (fairs), concerts and events. Katowice also offers values and attractions related to the intangible cultural heritage related to mining traditions, the history of Upper Silesia-especially the Silesian Uprisings (1919-1921) and Silesian Cuisine.

The turbulent development of the city Łódź in the 19th century was related to the industrial revolution. In 1820, Łódź obtained the status of an industrial settlement, a center of weaving and cloth production. It was also the beginning of the multiculturalism of this city inhabited mainly by Poles, Russians, Jews and Germans. The development of largescale Łódź began in 1839 with the launch of a steam engine in one of the manufactories. In the second half of In the nineteenth century, Łódź was one of the largest cities in the Kingdom of Poland and a powerful industrial center. Eclectic and Art Nouveau palaces of industrialists and houses of rich burghers appeared in the urban landscape. 1989 marked the beginning of the liquidation of the textile industry and economic changes in the city. Despite a quarter of a century of changes, the face of this city is often perceived as uninteresting and not worth visiting. Łódź develops cultural heritage tourism based on the multicultural landscape of an industrial city. This landscape is created by former textile factories, workers' housing estates and the opulence of Art Nouveau and eclectic tenement houses. Łódź is the capital of Polish Art Nouveau, former Manchester, a city of dialogue of four cultures and the Promised Land-these are the main elements of the cultural heritage of this city. Related to them are tourist attractions such as Piotrkowska 
Street, the Central Museum of Textiles, and palaces of Łódź industrialists, for example Poznański. This cultural heritage includes revitalized areas and post-industrial facilities such as Manufaktura-a former textile factory, which after revitalization is a shopping, service and entertainment center. After revitalization, the former municipal heat and power plant was transformed into the Science and Technology Center. In many post-factory buildings, especially at Piotrkowska Street, there are restaurants, clubs, exhibitions, etc. Łódź is also "Polish Hollywood". The famous film, theater and television school, the Museum of Cinematography and the Avenue of the Stars are located here. Therefore, Łódź builds the image of a tourist city on the basis of cultural heritage, not only post-industrial.

\section{Materials and Methods}

The research was carried out with a group of 250 respondents. The study group consisted mostly of women (64.2\%). The survey was conducted as a Google form in the first half of 2021. The respondents are residents of Kraków and the surrounding area. Kraków (approx. 780,000 residents) is the second largest city in terms of the number of residents and is a leading service and industrial center in Poland. The city is located in southern Poland on the Vistula River, and its well-developed tourist infrastructure and transport accessibility make the city one of the largest tourist centers in Poland.

Information was obtained from respondents from the region of Kraków, i.e., those operating in a city with tourism potential greater or similar to the cities studied: Wrocław, Gdańsk, Łódź and Katowice. Another significant factor is the fact that Krakow is located far from the cities studied, from $70 \mathrm{~km}$ in a straight line in the case of Katowice to $500 \mathrm{~km}$ in the case of Gdańsk. In this way, the situation in which the knowledge and opinions about dishes, events or tourist attractions result from the fact of living in a city associated with them was limited or eliminated.

Limiting the research area to only one city implies that the results might not be fully representative for the whole country. However, thanks to focusing on more homogenous group it was possible to omit the factor of spatial differences of the perception of particular cities. Residents of different locations in Poland might have very differentiated views regarding the cities, and the impact of familiarity on the perceived attractiveness might have been disturbed when analyzing opinions of people living in different regions.

The questions in the questionnaire were on how attractive the cities studied were perceived, as well as how familiar the respondents were with the tourist offer and how it was perceived. The questionnaire contained eight multichotomous questions. It was distributed among people living or working in Kraków using the Internet channels. For each element of the destination (attractions, events and dishes) a list of potential items was developed based on sightseeing sources.

First, the respondents were asked to indicate knowledge of traditional dishes related to Katowice (seven dishes), Wrocław (seven), Łódź (10) and Gdańsk (nine). The results of the study of familiarity with traditional dishes were based on three criteria: (1) I have eaten it, (2) I did not eat it, but I have heard about it, and (3) I have never heard about it (Table 1). Then, the respondents were asked to indicate knowledge of cyclical events in Katowice (12 events), Wrocław (28), Łódź (20), Gdańsk (11), and knowledge of the main tourist attractions of Katowice (10 attractions), Wrocław (12), Łódź (14) and Gdańsk (16). The results of the study of familiarity with events and tourist attractions were based on three criteria: (1) I have been there, (2) I have never been there, but I have heard about it, and (3) I have never heard about it (Table 2). 
Table 1. Knowledge of traditional dishes in Katowice, Wrocław, Łódź, and Gdańsk [\%].

\begin{tabular}{ccc}
\hline & \multicolumn{2}{c}{ Traditional Dishes } \\
\hline Katowice & 37.7 \\
Wrocław & I have eaten it & 26.1 \\
Łódź & 21.9 \\
Gdańsk & & 15.1 \\
\hline Katowice & I have not eaten it, but I have & 29.9 \\
Wrocław & heard about it & 31.8 \\
Lódź & & 24.1 \\
Gdańsk & & 28.9 \\
\hline
\end{tabular}

Source: Own study.

Table 2. Knowledge of the cyclical events and tourist attractions of Katowice, Wrocław, Łódź, and Gdańsk [\%].

\begin{tabular}{cccc}
\hline & & Cyclical Events & Tourist Attractions \\
\hline Katowice & & 4.6 & 16.4 \\
Wrocław & I have been there & 2.4 & 42.2 \\
Łódź & & 1.6 & 7.8 \\
Gdańsk & 3.2 & 35.3 \\
Katowice & I have never been & 39.0 & 42.1 \\
Wrocław & there, but I have & 23.6 & 40.1 \\
Łódź & heard about it & 18.2 & 36.2 \\
Gdańsk & & 29.1 & 36.8 \\
\hline
\end{tabular}

Source: Own study.

Subsequent questions included in the survey allowed for the determination of the percentage of respondents considering Katowice, Wrocław, Łódź and Gdańsk as cities attractive for tourists and places attractive to spend free time. Both in the case of the question regarding the recognition of Katowice, Wrocław, Łódź and Gdańsk as an attractive tourist area and the question regarding the recognition of these four cities as attractive areas for spending free time, the following response scale was applied: (a) definitely yes, (b) rather yes, (c) rather no, and (d) definitely not.

In the last phase of the analysis of the obtained statistical data, the correlation coefficients between the knowledge of traditional dishes, cyclical events and tourist attractions and the indications of Katowice, Wrocław, Łódź and Gdańsk as attractive cities for tourists were determined. Then, the correlation coefficients between the knowledge of traditional dishes, cyclical events and tourist attractions and the indications of Katowice, Wrocław, Łódź and Gdańsk as attractive places for spending free time were determined. Correlation coefficients were calculated for the full set of data on dishes, cyclical events and tourist attractions (Figures 2 and 3). These coefficients were also calculated for the three most frequently chosen dishes, cyclical events and attractions (Tables 3-5). 


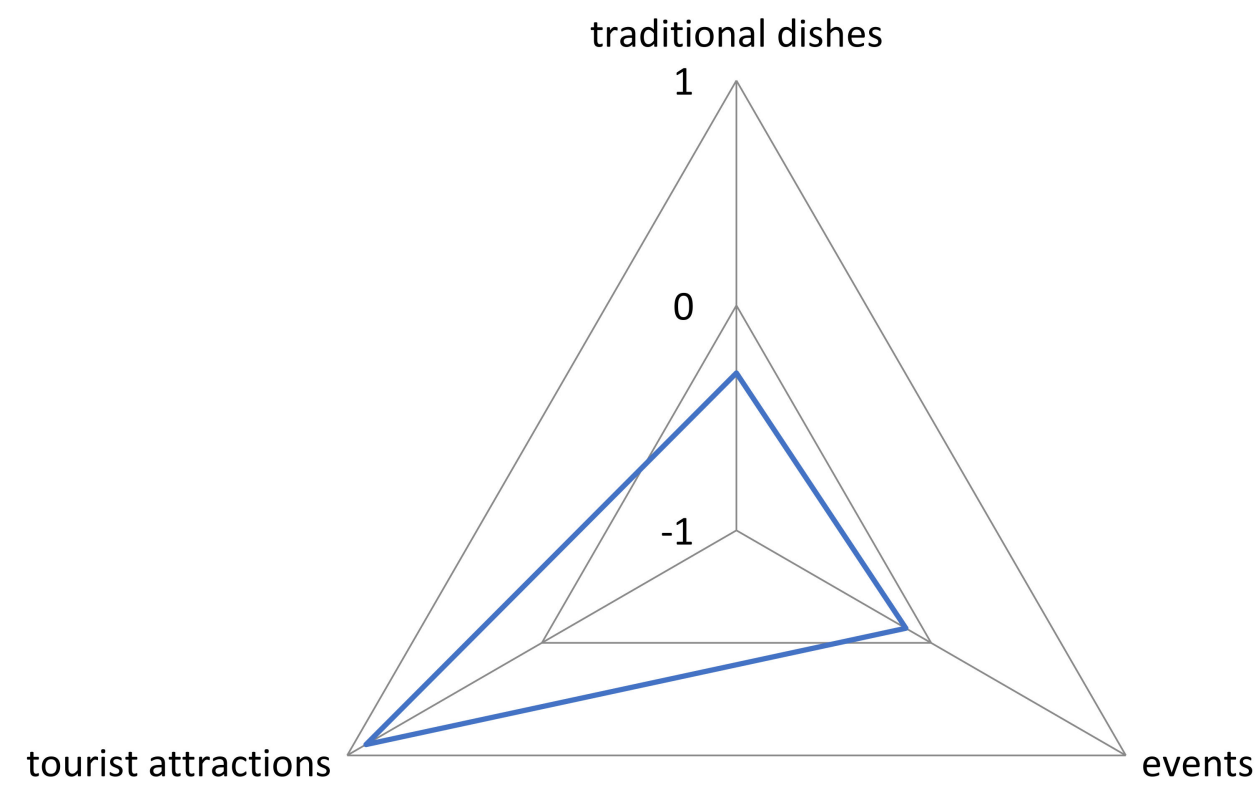

Figure 2. The relationship between the knowledge of traditional dishes, cyclical events, and tourist attractions with the cities being considered as attractive for tourists (the values of the correlation coefficient). Source: own study.

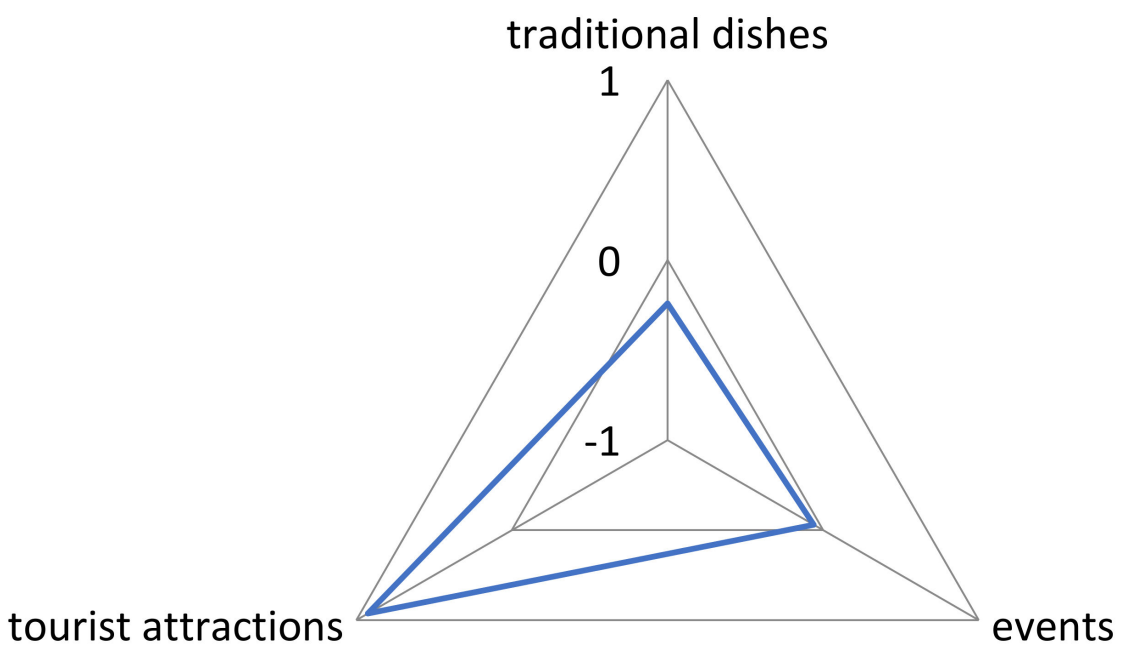

Figure 3. The relationship between the knowledge of traditional dishes, cyclical events, and tourist attractions with the cities being considered as attractive places to spend free time (the values of the correlation coefficient). Source: own study.

Table 3. Correlations of the knowledge of the most frequently chosen traditional dishes (\%) with the cities being considered attractive for tourists and attractive places to spend free time (\%).

\begin{tabular}{|c|c|c|c|c|c|c|}
\hline & \multirow{2}{*}{ (A) } & & \multirow{2}{*}{ (B) } & \multirow{2}{*}{ (C) } & \multicolumn{2}{|c|}{ Correlation Coefficient } \\
\hline & & & & & A/B & $\mathrm{A} / \mathrm{C}$ \\
\hline Katowice & $\begin{array}{l}\text { Sour soup, beef roulade, red cabbage and } \\
\text { Silesian noodles, krupniok (blood pudding) }\end{array}$ & 87.9 & 59.0 & 55.6 & \multirow[b]{2}{*}{-0.80} & \multirow[b]{2}{*}{-0.78} \\
\hline Wrocław & $\begin{array}{c}\text { Żurek wrocławski (sour soup of Wrocław), } \\
\text { yeast dough with cinnamon crumble, Wrocław } \\
\text { roasted sausage }\end{array}$ & 72.1 & 99.6 & 98.5 & & \\
\hline
\end{tabular}


Table 3. Cont.

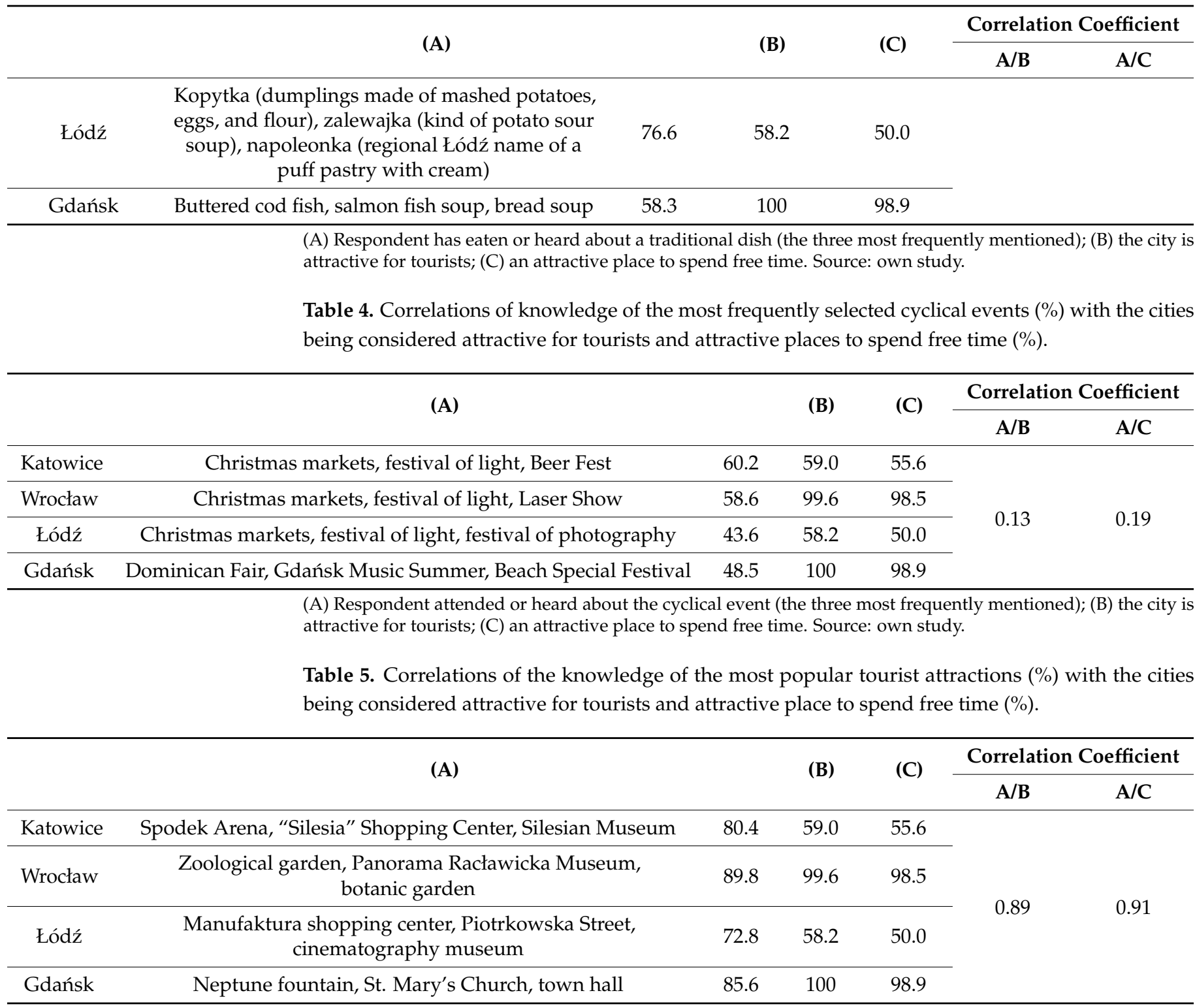

(A) The respondent knows the tourist attraction (was/has seen) or has heard about the attraction (the three most frequently mentioned). (B) The city is attractive for tourists. (C) An attractive place to spend free time. Source: own study.

Subsequent questions included in the survey allowed us to determine the percentage of respondents considering Katowice, Wrocław, Łódź, and Gdańsk as cities that were attractive for tourists and places that were attractive in which to spend free time. In the last phase of the analysis of the obtained statistical data, the correlation coefficients between the knowledge of traditional dishes, cyclical events, and tourist attractions and the consideration of Katowice, Wrocław, Łódź, and Gdańsk as attractive cities for tourists and for spending free time were calculated. Correlation was sought in the variant for the three most important dishes, cyclical events, and attractions (Tables 3-5), as well as in the full dataset for these three components (Figures 2 and 3).

\section{Results}

As a result of the diagnostic survey, a low level of knowledge of traditional dishes associated with the cities of Katowice, Wrocław, Łódź, and Gdańsk was observed (Table 1). On average, every third respondent has eaten or heard of such dishes. The lowest level of respondent participation was shown in the case of cyclical events organized in the 
examined cities (Table 2), with the awareness of these events below 30\% on average. Higher recognition, on average at the level of $40 \%$ of objects, was demonstrated in the case of tourist attractions (Table 2). The greatest differentiation was recorded in the level of participation in tourist attractions, with a clear predominance of facilities located in Wrocław and Gdańsk and negligible percentages for Łódź and Katowice.

There was no correlation between the knowledge of traditional dishes and the respondents' consideration of the city they come from as attractive for tourists and as an attractive place to spend free time (Figures 2 and 3).

Moreover, participation and knowledge of cyclical events contained in the survey do not affect the assessment of these cities in terms of their attractiveness. Different results were obtained in the case of considering the most important tourist attractions of cities and their evaluation as attractive centers for tourists.

The distribution of the values of correlation coefficients, illustrated in Figures 1 and 2 and calculated on the basis of all traditional dishes (33 dishes), cyclical events (71 events), and tourist attractions (50 attractions) included in the survey, is confirmed in the case of analogous analyses of three dishes, events, and attractions most often indicated by respondents (Tables 3-5).

\section{Discussion}

The study was based on four cities belonging to the group of the largest cities in Poland in terms of the number of inhabitants, and they are cities that are significant industrial and service centers. All four cities have a very favorable communication location. They are located on the main railway and road routes of European rank. Katowice is home to one of the largest airports in Poland (Katowice-Pyrzowice), while smaller airports can be found in Wrocław, Gdańsk, and Poznań. Gdańsk is one of the largest port cities on the Baltic Sea.

Important in the context of the tourist attractiveness of the studied cities is the consideration of their historical parts or selected monuments as monuments of history. This honorable inscription is given to places or objects by the President of the Poland, and the Institute of National Heritage promotes them as outstanding examples of Polish heritage. Hence, it is easy to learn about the tourist attractions in these cities both directly and indirectly. Clearly distinguished are the cities that are historical centers shaped in the Middle Ages: Wrocław and Gdańsk. These cities boast the largest concentration of sites with expressive and outstanding architecture. Some of these are recognizable on a national scale, e.g., the port crane and the Neptune fountain in Gdańsk. Wrocław, on the other hand, is known for its historical buildings on the island of Ostrów Tumski, the zoological garden, the Panorama Racławicka museum, and Centennial Hall (Hala Stulecia) — a site on the UNESCO heritage list. Little can be found out about the tourist attractions in Katowice and Łódź via direct investigation. These cities were formed in the nineteenth century as industrial cities, and, despite the change in function from industrial to service, they are considered as industrial centers. Geographical education had a significant role in creating such an image of these cities [75]. This image has not been fundamentally changed by the developing tourist functions [76].

Industrial heritage is used in the tourist promotion of Katowice and Łódź. The promotion of Katowice is based on selected sites and post-industrial areas, e.g., colonies (the mining estates of Nikiszowiec and Giszowiec) and the intangible mining heritage. This means that tourist attractions in Katowice are better known from direct exploration than those in Łódź, which clearly differs from other cities in terms of attractiveness. Łódź was observed to not promote expressive post-industrial sites or palaces despite the fact that many of them are full of Art Nouveau architecture. Moreover, the Central Museum of Textiles in a former textile factory is not recognizable on a nationwide scale. In this city, Art Nouveau architectural ensembles, e.g., buildings on Piotrkowska Street, can be found, and museums occupy palaces of former magnates. As such, the uniqueness of these buildings is blurred. In the case of Łódź, the thesis is also confirmed that entry on the elite list of cultural heritage monuments of history does not always automatically translate into an 
increase in the number of visitors, and thus an increase in tourist attractiveness [77]. In the case of Łódź, it would be necessary to promote specific sites or features of the historical city center determining the multicultural landscape of the nineteenth century industrial city preserved to this day.

The conducted research indicated a strong correlation between the knowledge of tourist attractions and the attractiveness of the city as a destination for tourism or leisure. It turns out, however, that among the most recognizable tourist attractions, objects related to cultural and historical heritage in Wrocław, Łódź, and Katowice account for only a small share. On the other hand, heritage objects have a decisive impact on tourist attractiveness in Gdańsk (Neptune fountain, St. Mary's Church, and the town hall). They are also noticeable in Łódź (Piotrkowska Street and Museum of Cinematography). In Wrocław, the most recognizable attractions are the zoological garden, botanical garden, and the Panorama Racławicka Museum. Less known than these attractions are historical sites of outstanding architectural and historical value e.g., a Gothic cathedral and Baroque buildings and the Centennial Hall (Hala Stulecia) inscribed on the UNESCO Heritage List. Therefore, entry on the elite list does not always determine the recognition of tourist attractions [77]. In Katowice and Łódź, the contemporary buildings that were built in post-industrial areas are the most famous. In Katowice, these are the Silesian Museum, the "Spodek" Sports and Entertainment Hall, and the "Silesia" Shopping Center, and the Manufaktura shopping and entertainment center is representative of this in Łódź.

The ranking of the surveyed cities in terms of knowledge of traditional dishes is slightly different. The most famous, both from direct and indirect exploration are the dishes in Katowice and Wrocław, followed by those in Gdańsk and Łódź. It should be noted that the traditional cuisine of the Upper Silesian region compared with other regional cuisines is expressed through the regionalism of dishes, e.g., sour soup-a soup clearly associated on a nationwide scale with this region, as well as beef roulade, red cabbage and Silesian noodles (potato noodles with a characteristic hole), and krupniok (blood pudding). While Silesian noodles are unique, they are widespread throughout Poland, but their proper name clearly indicates their origin in the Silesian region. Thus, even if a tourist has a problem finding a restaurant in Katowice serving these dishes, they are able to find out about them from hearing about them. Upper Silesian cuisine on a nationwide scale is distinguished by strong regionalism, and it is undoubtedly an element of the intangible heritage of the region.

A weak regionalism is observable in the case of dishes promoted in other cities, especially in Łódź and Wrocław. Dishes promoted in these cities as regional occur throughout Poland. They have a similar taste and differ only in adjectival name or additives. Examples of this are "Żurek wrocławski" (Wrocław) and "napoleonka" (Łódź). "Żurek" is also a sour soup, which is widespread in Poland with different adjectival names depending on the region (e.g., Kujawski sour rye soup and Zamość sour soup). It is served with potatoes or with egg. "Napoleonka" is a puff pastry with cream known by this name in Łódź. The same cake in Małopolska is called "cream-cookie". The situation in Gdańsk is somewhat different. In this port city, almost every tourist has to eat fish. Fish dishes are served in every restaurant. However, it is difficult to find fish prepared in the Gdansk way, i.e., so that this dish in terms of taste and method of serving is clearly associated with Gdańsk.

Knowledge of the culinary traditions and local cuisine of the destination is poorly correlated with a favorable perception of the tourist attractiveness of the destination or as a holiday destination. Culinary traditions are a poorly recognizable element of the image of Polish cities and regions. Hence, culinary tourism in Poland is poorly developed. Outside Upper Silesia (Katowice), the dishes referred to in the menu as regional have a very similar taste and differ only in the adjectival name indicating their regionalism. The gastronomic offer is based on traditional Polish dishes, while regional dishes occupy a niche position. Restaurants that serve them are not easily accessible, which makes it difficult for tourists to find them, and they often give up looking for them.

Research on culinary tourism in Gdańsk, Wrocław, Katowice and Łódź emphasized the knowledge of regional dishes. In spatial terms, in the authors' intention, eating these dishes 
could be both the main tourist intention, and could be associated with their consumption while visiting cities or participating in events. Culinary tourism has a strong position in the Polish scientific literature. New publications indicate that Polish culinary tourism is not as popular as in Western Europe [78]. It is also pointed out that there are no empirical studies [79]. The presented research enters this gap. For the authorities of these and other cities, they are an indication on how to build a strategy for the development of the culinary tourism sector, especially in the spatial aspect (tourist space and geographical space) [80]. They show which of the many regional dishes should be particularly supported, promoted and disseminated. In this way, it should be sought that food services are equivalent to other tourist values and increase the attractiveness of the entire package of tourist services. Then the tourist will receive additional impressions and satisfaction [81].

Knowledge of cyclical events shows similarities in the three cities of Katowice, Łódź, and Wrocław. Events are definitely better known from directly hearing about them than direct investigation. There is also an unusual dependence-along with the increase in the tourist attractiveness of the city, participation in events decreases, hence the conclusion that tourists visiting the studied cities were not interested in participating in high culture events. They were more interested in occasional events, e.g., Christmas markets and the festival of light. Events typical of these cities were also indicated: beer fest-Katowice; Laser Show-Wrocław; and the festival of photography-Lódź. Against the background of these cities, Gdańsk stands out. Here, the Dominican Fair, an event deeply rooted in the history of the city, is one of the most famous events, and music events, including the Baltic Sea Festival closely related to Gdańsk, is also held in this city. However, a high knowledge level of the tourist attractions in this city is accompanied by little knowledge of events. These considerations are summed up by the statement that events as tourist attractions are poorly correlated with both the perception of the city as attractive for tourism and for leisure.

\section{Conclusions}

The resented results allowed us to confirm only one of the hypotheses (H1). Familiarity with tangible tourists attractions is significantly correlated with perception of attractiveness of the city. At the same time, the two other hypotheses ( $\mathrm{H} 2$ and $\mathrm{H} 3)$ had to be rejected. No significant correlation was found between familiarity with events and perceived attractiveness of the city and between familiarity with culinary traditions and attractiveness of the city. The presented literature review allowed for the expectation that familiarity with tourism attractions can be an important factor in positively influencing the destination image. There was no earlier research in the case of familiarity with events and with culinary traditions and their impacts on perceived attractiveness of a destination. Furthermore, it was expected that the impact of those factors might be less significant than in the case of familiarity with tangible attractions. Still, the complete lack of correlation can be a bit surprising and needs some further investigation as to its justification.

At first it is worth to put attention into the observed level of familiarity of particular researched items. In the long lists of tangible attractions, events and dishes characteristic for individual cities a big number of items remained completely unknown, and all or almost all respondents have never heard about them. Still, the overall level of familiarity of tourist attractions remains much higher than the level of familiarity with events and dishes. In the case of all researched cities there was at least one attraction that was known by a majority of respondents. It is characteristic that in the case of the cities with higher detected perceived attractiveness the number of such known attractions was higher, and usually respondents' familiarity with them was also higher; more people also indicated having previous personal experiences with them. A similar situation can be observed in the cases of events and dishes. A small number of items captured good familiarity in the case of all cities. This could lead to a very important practical conclusion, that when promoting a tourist city it is more efficient to find effective hallmarks regarding all presented categories, 
instead of the presentation of big numbers of items that after all remain unrecognizable for most of the receivers of the promotional message.

This publication is based on an original research methodology which, due to its universality, can be used in researching the tourist attractiveness of other cities and regions. It fits into the methodology of broadly understood cultural tourism. It also sets the direction for a comprehensive study of tourist attractions of a given place and their mutual relations. This theoretical dimension of the article is combined with the practical aspect. This is a practical recommendation for tourist decision-makers to indicate that the image of the place should be built on the equal promotion of tourist values and attractions. Only then would the tourist notice all the components of the tourist space and freely combine them with interesting tourist values and attractions. The general low level of numerous elements of researched destinations suggests that the policy-makers should concentrate their promotional activities on the limited number of elements which have the potential to gain high recognizability or even to become a hallmark of the city. Otherwise, by spreading the efforts on promoting numerous items they may achieve no results, and most of the promoted items would remain unfamiliar to most of the potential visitors. In the current study, we found a strong correlation between the knowledge about the most popular tourist attractions and the city considered to be an attractive tourist destination and an attractive place to spend free time. Tourist promotion of a city does not always have to be based on cultural and historical heritage. The tourist attractiveness of a city is most strongly influenced by individual objects strongly associated with the history of the city, entertainment and shopping, and an expressive cultural landscape. This confirms the notion that knowledge of the tangible tourist attractions of a destination is correlated with a more favorable perception of the attractiveness of the destination. The inclusion of a tourist attraction (object) in an elite heritage group at both national (historical monument) or international (UNESCO Heritage List) level does not always determine recognition. The object should be promoted in a special way.

The negative correlation coefficient between knowledge of culinary traditions and the city being considered to be an attractive tourist destination suggests that culinary traditions have little impact on the perception of the attractiveness of cities. This is associated with a lack of or poor memory of taste sensations associated with the destinations. One of the reasons is the low availability of regional dishes in a widely available catering network. Only in the case of Katowice can it be stated that knowledge of the culinary traditions and local cuisine of the destination is correlated with a more favorable perception of the attractiveness of the destination. However, it should be taken into account that knowledge of the culinary traditions of Upper Silesia is supra-regional. In the case of other cities, such knowledge does not go beyond the local level. Local, traditional gastronomy based on regional cuisine should be equal to other values and tourist attractions. This applies to the promotion of dishes, products, catering facilities and culinary events. A well-functioning regional cuisine is a factor of local development.

There is poor correlation between participation in events in cities considered to be attractive tourist locations and attractive places in which to spend free time. A closer relationship is observable in the case of hearing knowledge about events and the attractiveness of cities. In all cities, occasional events, e.g., Christmas markets, are well known.

The initial research cannot claim to fill the scientific gap perfectly. Instead, the research is intended to underline the significance of the issue and highlight the directions of future research. Those directions are numerous and diverse. Future research needs to extend the study to include more elements of tourist destinations. Presented results also showed the need for better understanding of the idea of familiarity with the particular elements of destinations. The method of studying it is likely to be further developed, as in the presented results the surprisingly very low level of familiarity with particular items was one of the reasons why the correlation between surveyed values (destination elements and perceived attractiveness) was disturbed. That is why rejecting hypotheses $\mathrm{H} 2$ and $\mathrm{H} 3$ should not be treated as general information about the low impact of familiarity with events and culinary 
traditions on the perceived attractiveness. Finally, there is a strong need for replicating the research in different places, especially in other countries, and also on an international scale. It would be also very educative to see how discovered relations exist in the context of tourist destinations of other kinds, like mountain or seaside resorts, nature parks, rural areas, etc.

The directions of the future research outlined above mirror the limitations of the presented research. The conclusions are based on particular geographical locations and the results gathered in other places might differ. Further analysis might also better study the impact of social characteristics of particular respondents and their impact on the level of familiarity. It is probable that young people might be familiar with other attractions, events and dishes than elderly people. The same could be said regarding the level of education, wealth, family status, etc.

An important limitation of the presented results is the fact that the random sampling did not concern respondents participation in different forms of tourism. The presented results reflect the perception of a general group of tourists, and this might be also a reason why elements connected with the realization of special interests were underestimated. It is likely that the familiarity with events dedicated to smaller groups of lovers of particular kinds of art (like music festivals), sport (like sporting events) or professional activity (business and political events) do not impact the perception of most tourists, but can be of crucial importance for their smaller target groups. The same can be stated about the role of culinary traditions. That is the reason why one of the most urgent directions of the future research within the topic is repeating the survey among the representatives of groups of special interests.

Additionally, most of the responses were gathered in a time of rather limited yet impact the COVID-19 pandemics and its impact on the perception of the attractiveness of particular cities is unknown. However, it can be noticed that in many places the demand for urban tourism was limited as a result of the pandemic.

Author Contributions: Conceptualization, M.S. and M.Ż.; methodology, M.S. and M.Ż; software, W.W.; validation, W.W.; formal analysis, W.W. All authors have read and agreed to the published version of the manuscript.

Funding: The researched was financially supported by the project: Comprehensive conditions, course and effects of the development of tourism and recreation on the example of selected regions in the context of the evolution and development of trends in tourism financed by Pedagogical University in Cracow, BN. 610-114/PBU/2020.

Institutional Review Board Statement: Not applicable.

Informed Consent Statement: Not applicable.

Data Availability Statement: Not applicable.

Conflicts of Interest: The authors declare no conflict of interest.

\section{References}

1. McIntosh, R.W.; Goeldner, C.R. Tourism Principles. In Practices, Philosophy, 6th ed.; John Wiley: New York, NY, USA, 1990.

2. Das, D.; Sharma, S.K.; Mohapatra, P.K.; Sarkar, A. Factors influencing the attractiveness of a tourist destination: A case study. J. Serv. Res. 2007, 7, 103-134.

3. Buhalis, D. Marketing the competitive destination of the future. Tour. Manag. 2000, 21, 97-116. [CrossRef]

4. $\quad$ Decrop, A. Vacation Decision Making; CABI: Wallingford, UK, 2006.

5. Crompton, J.L. An assessment of the image of Mexico as a vacation destination and the influence of geographical location upon that image. J. Travel Res. 1979, 17, 18-23. [CrossRef]

6. Echtner, C.M.; Ritchie, J.B. The meaning and measurement of destination image. J. Tour. Stud. 1991, 2, 2-12.

7. Chen, C.F.; Tsai, D. How destination image and evaluative factors affect behavioral intentions? Tour. Manag. 2007, $28,1115-1122$. [CrossRef]

8. Tasci, A.D.; Gartner, W.C. Destination image and its functional relationships. J. Travel Res. 2007, 45, 413-425. [CrossRef]

9. Cai, L.; Wu, B.; Bai, B. Destination image and loyalty. Tour. Rev. Int. 2003, 7, 153-162. [CrossRef] 
10. Formica, S.; Uysal, M. Destination attractiveness based on supply and demand evaluations: An analytical framework. J. Travel Res. 2006, 44, 418-430. [CrossRef]

11. Hu, Y.; Ritchie, J.B. Measuring destination attractiveness: A contextual approach. J. Travel Res. 2006, 32, 25-34.

12. Baloglu, S.; McCleary, K.W. US international pleasure travelers' images of four Mediterranean destinations: A comparison of visitors and non visitors. J. Travel Res. 1999, 38, 144-152. [CrossRef]

13. Liu, H.; Li, X.R.; Cárdenas, D.A.; Yang, Y. Perceived cultural distance and international destination choice: The role of destination familiarity, geographic distance, and cultural motivation. J. Destin. Mark. Manag. 2018, 9, 300-309. [CrossRef]

14. Gursoy, D.; Del Chiappa, G.; Zhang, Y. Impact of destination familiarity on external information source selection process. J. Destin. Mark. Manag. 2018, 8, 137-146. [CrossRef]

15. Yale, P. From Tourist Attractions to Heritage Tourism; ELM Publications: Helsinki, Finland, 1991.

16. Kušen, E. A system of tourism attractions. Tour. Int. Interdiscip. J. 2010, 58, 409-424.

17. Richards, G. (Ed.) Cultural Attractions and European Tourism; Richards, G. (Ed.) CABI: Wallingford, UK, 2001.

18. Richards, G.; Wilson, J. The impact of cultural events on city image: Rotterdam, cultural capital of Europe 2001. Urban Stud. 2004, 41, 1931-1951. [CrossRef]

19. Bracalente, B.; Chirieleison, C.; Cossignani, M.; Ferrucci, L.; Gigliotti, M.; Ranalli, M.G. The economic impact of cultural events: The Umbria Jazz music festival. Tour. Econ. 2011, 17, 1235-1255. [CrossRef]

20. Hernández-Mogollón, J.M.; Duarte, P.A.; Folgado-Fernández, J.A. The contribution of cultural events to the formation of the cognitive and affective images of a tourist destination. J. Destin. Mark. Manag. 2018, 8, 170-178. [CrossRef]

21. Long, L.M. (Ed.) Culinary Tourism; University Press of Kentucky: Lexington, KY, USA, 2004.

22. Harrington, R.J.; Ottenbacher, M.C. Culinary tourism-A case study of the gastronomic capital. J. Culin. Sci. Technol. 2010, 8, 14-32. [CrossRef]

23. Green, G.P.; Dougherty, M.L. Localizing linkages for food and tourism: Culinary tourism as a community development strategy. Community Dev. 2008, 39, 148-158. [CrossRef]

24. Maitland, R.; Ritchie, B.W. (Eds.) City Tourism: National Capital Perspectives; Cabi: Wallingford, UK, 2009.

25. Bellini, N.; Pasquinelli, C. Tourism in the City; Springer: Cham, Switzerland, 2017.

26. Bock, K. The changing nature of city tourism and its possible implications for the future of cities. Eur. J. Futures Res. 2015, 3, 1-8. [CrossRef]

27. Żemła, M. Reasons and consequences of overtourism in contemporary cities-Knowledge gaps and future research. Sustainability 2020, 12, 1729. [CrossRef]

28. Koens, K.; Postma, A.; Papp, B. Is overtourism overused? Understanding the impact of tourism in a city context. Sustainability 2018, 10, 4384. [CrossRef]

29. Barbhuiya, M.R. Overtourism in Indian cities: A case study of Nainital. Int. J. Tour. Cities 2020, 7, 702-724. [CrossRef]

30. Zmyślony, P.; Kowalczyk-Anioł, J.; Dembińska, M. Deconstructing the overtourism-related social conflicts. Sustainability 2020, 12, 1695. [CrossRef]

31. Kowalczyk, A. Geografia Turyzmu; Wydawnictwo Naukowe PWN: Warszawa, Poland, 2000.

32. Kim, D.; Perdue, R.R. The influence of image on destination attractiveness. J. Travel Tour. Mark. 2011, 28, 225-239. [CrossRef]

33. Gryszel, P.; Walesiak, M. Zastosowanie uogólnionej miary odległości GDM w ocenie atrakcyjności turystycznej powiatów Dolnego Śląska. Folia Tur. 2014, 31, 124-147.

34. Backman, S.J.; Uysal, M.; Backman, K. Regional analysis of tourism resources. Ann. Tour. Res. 1991, 18, 323-327. [CrossRef]

35. Gołembski, G. (Ed.) Regionalne Aspekty Rozwoju Turystyki; PWN: Warszawa, Poland, 1999.

36. An, L.T.; Markowski, J.; Bartos, M.; Rzenca, A.; Namiecinski, P. An evaluation of destination attractiveness for nature-based tourism: Recommendations for the management of national parks in Vietnam. Nat. Conserv. 2019, 32, 51. [CrossRef]

37. Cooper, C.; Fletcher, J.; Gilbert, D.; Fyall, A.; Wanhill, S. Tourism: Principles and Practice; Pearson Education: London, UK, 2005.

38. Kruczek, Z. Atrakcyjność turystyczna uzdrowisk karpackich. In Uzdrowiska o Ich Funkcja Turystyczno-Lecznicza; Szromek, A.R., Ed.; Proksenia: Kraków, Poland, 2012; pp. 59-72.

39. Ziółkowska-Weiss, K.; Żemła, M. Propozycja metody pomiaru postrzeganej atrakcyjności turystycznej państw grupy wyszehradzkiej. Res. Pap. Wroc. Univ. Econ. 2018, 535, 205-215. [CrossRef]

40. Ritchie, J.B.; Zins, M. Culture as determinant of the attractiveness of a tourism region. Ann. Tour. Res. 1978, 5, 252-267. [CrossRef]

41. Gearing, C.E.; Swart, W.W.; Var, T. Establishing a measure of touristic attractiveness. J. Travel Res. 1974, 12, 1-8. [CrossRef]

42. Tang, J.C.; Rochananond, N. Attractiveness as a tourist destination: A comparative study of Thailand and selected countries. Socio-Econ. Plan. Sci. 1990, 24, 229-236. [CrossRef]

43. Hong-Bumm, K. Perceived attractiveness of Korean destinations. Ann. Tour. Res. 1998, 25, 340-361. [CrossRef]

44. Ćulić, M.; Vujičić, M.D.; Kalinić, Č.; Dunjić, M.; Stankov, U.; Kovačić, S.; Anđelković, Ž. Rookie Tourism Destinations-The Effects of Attractiveness Factors on Destination Image and Revisit Intention with the Satisfaction Mediation Effect. Sustainability 2021, 13, 5780. [CrossRef]

45. Szubert, M.; Warcholik, W.; Żemła, M. The Influence of Elements of Cultural Heritage on the Image of Destinations, Using Four Polish Cities as an Example. Land 2021, 10, 671. [CrossRef]

46. Philipp, S.F. Racial differences in the perceived attractiveness of tourism destinations, interests, and cultural resources. J. Leis. Res. 1993, 25, 290. [CrossRef] 
47. Cho, V. Linking location attractiveness and tourist intention. Tour. Hosp. Res. 2008, 8, 220-224. [CrossRef]

48. Islam, S.; Hossain, M.K.; Noor, M.E. Determining drivers of destination attractiveness: The Case of nature-based tourism of Bangladesh. Int. J. Mark. Stud. 2017, 9, 10-23. [CrossRef]

49. Hunt, J.D. Image as a factor in tourism development. J. Travel Res. 1975, 13, 1-7. [CrossRef]

50. Fakeye, P.C.; Crompton, J.L. Image differences between prospective, first-time, and repeat visitors to the Lower Rio Grande Valley. J. Travel Res. 1991, 30, 10-16. [CrossRef]

51. Gallarza, M.G.; Saura, I.G.; García, H.C. Destination image: Towards a conceptual framework. Ann. Tour. Res. 2002, 29, 56-78. [CrossRef]

52. Choi, W.M.; Chan, A.; Wu, J. A qualitative and quantitative assessment of Hong Kong's image as a tourist destination. Tour. Manag. 1999, 20, 361-365. [CrossRef]

53. Beerli, A.; Martin, J.D. Factors influencing destination image. Ann. Tour. Res. 2004, 31, 657-681. [CrossRef]

54. Pike, S.; Ryan, C. Destination positioning analysis through a comparison of cognitive, affective, and conative perceptions. J. Travel Res. 2004, 42, 333-342. [CrossRef]

55. Baloglu, S.; Brinberg, D. Affective images of tourism destinations. J. Travel Res. 1997, 35, 11-15. [CrossRef]

56. Kim, H.; Richardson, S.L. Motion picture impacts on destination images. Ann. Tour. Res. 2003, 30, 216-237. [CrossRef]

57. Milman, A.; Pizam, A. The role of awareness and familiarity with a destination: The central Florida case. J. Travel Res. 1995, 33, 21-27. [CrossRef]

58. Prebensen, N.K. Exploring tourists' images of a distant destination. Tour. Manag. 2007, 28, 747-756. [CrossRef]

59. Afshardoost, M.; Eshaghi, M.S. Destination image and tourist behavioural intentions: A meta-analysis. Tour. Manag. 2020, 81, 104154. [CrossRef]

60. Ahmad, A.; Jamaludin, A.; Zuraimi NS, M.; Valeri, M. Visit intention and destination image in post-COVID-19 crisis recovery. Curr. Issues Tour. 2021, 24, 2392-2397. [CrossRef]

61. Ryan, C.; Cave, J. Structuring destination image: A qualitative approach. J. Travel Res. 2005, 44, 143-150. [CrossRef]

62. Gartner, W.C.; Hunt, J.D. A method to collect detailed tourist flow information. Ann. Tour. Res. 1988, 15, 159-172. [CrossRef]

63. Baloglu, S. Image variations of Turkey by familiarity index: Informational and experiential dimensions. Tour. Manag. 2001, 22, 127-133. [CrossRef]

64. Prentice, R. Tourist familiarity and imagery. Ann. Tour. Res. 2004, 31, 923-945. [CrossRef]

65. Tan, W.K.; Wu, C.E. An investigation of the relationships among destination familiarity, destination image and future visit intention. J. Destin. Mark. Manag. 2016, 5, 214-226. [CrossRef]

66. Horng, J.S.; Liu, C.H.; Chou, H.Y.; Tsai, C.Y. Understanding the impact of culinary brand equity and destination familiarity on travel intentions. Tour. Manag. 2012, 33, 815-824. [CrossRef]

67. Chi, H.K.; Huang, K.C.; Nguyen, H.M. Elements of destination brand equity and destination familiarity regarding travel intention. J. Retail. Consum. Serv. 2020, 52, 101728. [CrossRef]

68. Huang, L.; Gursoy, D.; Xu, H. Impact of personality traits and involvement on prior knowledge. Ann. Tour. Res. 2014, 48, 42-57. [CrossRef]

69. Kim, S.B.; Kwon, K.J. Examining the relationships of image and attitude on visit intention to Korea among Tanzanian college students: The moderating effect of familiarity. Sustainability 2018, 10, 360. [CrossRef]

70. Lee, J.; Graefe, A.R.; Burns, R.C. Examining the antecedents of destination loyalty in a forest setting. Leis. Sci. 2007, $29,463-481$. [CrossRef]

71. Wen, J.; Huang, S. The effects of push and pull travel motivations, personal values, and destination familiarity on tourist loyalty: A study of Chinese cigar tourists to Cuba. Asia Pac. J. Tour. Res. 2019, 24, 805-821. [CrossRef]

72. Kesgin, M.; Murthy, R.S.; Pohland, L.W. Residents as destination advocates: The role of attraction familiarity, destination image. J. Hosp. Tour. Insights 2019, 2, 55-74. [CrossRef]

73. Ha, J.; Jang, S.S. Perceived values, satisfaction, and behavioral intentions: The role of familiarity in Korean restaurants. Int. J. Hosp. Manag. 2010, 29, 2-13. [CrossRef]

74. Severt, K.; Hahm, J.J. Impact of political event and political affliation on destination image and a longitudinal approach of image change. J. Destin. Mark. Manag. 2020, 15, 100406. [CrossRef]

75. Szubert, M.; Żemła, M. The Role of the Geographical Textbooks in Grounding Negative Stereotypes of a Tourism Destination-The Case of Upper Silesian Conurbation in Poland. Adm. Sci. 2019, 9, 42. [CrossRef]

76. Żemła, M.; Szubert, M. Wizerunek miast konurbacji górnośląskiej-Wyzwanie przełamywania stereotypów. Ann. Univ. Paedagog. Crac. Studia Geogr. 2019, 13, 57-77. [CrossRef]

77. Ziarkowska, J. Dziedzictwo uznane-Wpis na listę UNESCO a atrakcyjność turystyczna (na przykładnie Tarnowskich Gór). Tur. Kult. 2019, 3, 53-76.

78. Orłowski, D. Turystyka kulinarna w Polsce-Wstępne badania nad fenomenem zjawiska. Tur. Kult. 2016, 5, 60-100.

79. Buczkowski-Gołąbek, K. Kulinaria w turystyce oraz turystyka kulinarna. Tur. Kult. 2016, 6, 221-235.

80. Kowalczyk, A. Turystyka kulinarna-Podejścia 'geograficzne' i niegeograficzne. Tur. Kult. 2016, 5, $29-59$.

81. Stasiak, A. Turystyka kulinarna w gospodarce doświadczeń. Tur. Kult. 2016, 5, 6-28. 